\title{
糖尿病透析慢性心不全に対する レニン・アンジオテンシン系抑制薬の効果
}

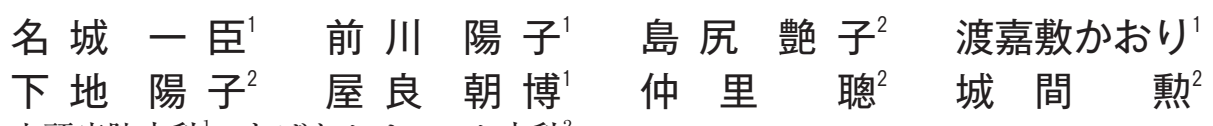

中頭病院内科 ${ }^{1}$ ちばなクリニック内科 ${ }^{2}$

キーワード : 左心機能, 糖尿病, 血液透析, レニン・アンジオテンシン系抑制薬, 慢性心不全

〈要旨〉

非透析患者で慢性収縮性心不全に対するレニン・アンジオテンシン系抑制薬（RA 系抑制薬）の有効性は確立して いる. 透析治療で, 特に心不全合併時は適切な dry weight (DW) 維持が重要であるが, 心疾患例では DW 設定困難 な場合があり, また重症例ほど DW の安全域は狭い. 透析導入例における糖尿病（DM）患者の割合は年々増大. DM 例においては透析中の血圧低下が多く, 特に心不全合併時には透析血圧が不安定性で, DW の設定, 維持に難 渋する場合がある. このような症例で RA 系抑制薬の効果が期待される. しかし，透析慢性心不全における RA 系 抑制薬の検討は不十分である. EF 50\%未満の DM 透析慢性心不全患者において RA 系抑制薬の有効性を検討した.

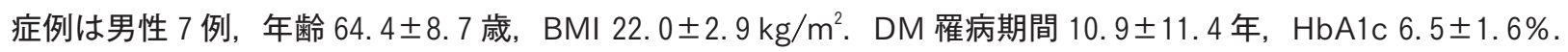
DM 治療は食事療法 2 例, 経口血糖降下剂 4 例, インスリン治療 1 例. 透析期間 49.7 444.3 か月. 全例 NYHA class II. 心疾患は DCM 1 例, 虚血性心疾患 6 例. 投与薬剂は enalapril 1 例, Iosartan 1 例, valsartan 3 例, telmisartan 2 例. RA 系抑制薬は常用量上限を目標として漸増した. 目標量に対して到達投与量は $82.1 \pm 24.9 \%$,

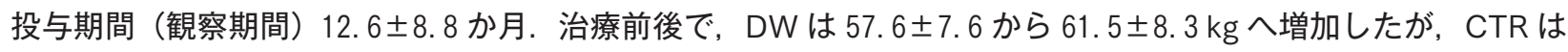

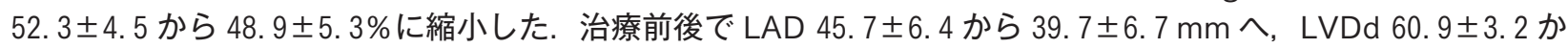
ら 52.2 $25.5 \mathrm{~mm}$ へ縮小した. $\mathrm{EF}$ も $39.8 \pm 8.0$ から $55.0 \pm 8.6 \%$ に改善した. 透析時血圧, 脈拍数は変化なし. 以 上, RA 系抑制薬により, DW 増加にもかかわらず透析 DM 慢性心不全例で CTR 減少, 左心機能改善を認めた.

\section{Effect of renin-angiotensin system inhibitors in diabetic dialysis patients with chronic heart failure}

Kazutaka Nashiro', Youko Maekawa', Tsuyako Shimajiri', Kaori Tokashiki', Youko Shimoji Tomohiro Yara', Satoshi Nakazato ${ }^{2}$ and Isao Shiroma ${ }^{2}$

Department of Internal Medicine, Nakagami Hospital ${ }^{1}$; Department of Internal Medicine, Chibana Clinic ${ }^{2}$

Key words : left ventricular function, diabetes, hemodialysis, renin-angiotensin system inhibitors, chronic heart failure

〈Abstract〉

The effectiveness of renin-angiotensin system inhibitors（RA inhibitors）in chronic systolic heart failure (HF) was established. In dialysis therapy, an appropriate dry weight (DW) must be maintained, especially for HF patients. The numbers of diabetic patients have been increasing among patients starting dialysis. In diabetics, especially those with HF, blood pressure (BP) can be unstable during dialysis, which may make it difficult to maintain DW. RA inhibitors may be helpful in diabetic dialysis patients with chronic HF (CHF). RA inhibitors have not been sufficiently studied in dialysis patients, to date. We studied the effectiveness of RA inhibitors in diabetic CHF patients on maintenance dialysis therapy, with a left ventricular ejection fraction (LVEF) less than $50 \%$. The cohort included seven male patients with an average age of $64.4 \pm 8.7$ years and a BMI of $22.0 \pm 2.9 \mathrm{~kg} / \mathrm{m}^{2}$. The

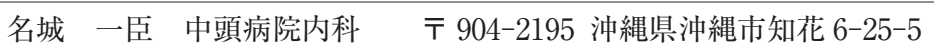

Kazutaka Nashiro Tel : 098-939-1300 Fax : 098-937-8699 E-mail : knashiro@nakagami.or.jp

〔受付日：2008 年 8 月 1 日, 受理日：2008 年 11 月 17 日] 
average duration of diabetes was $10.9 \pm 11.4$ years, and $\mathrm{HbA} 1 \mathrm{c}$ was $6.5 \pm 1.6 \%$. Two patients used diet therapy ; four patients, oral hypoglycemic agents ; and one patient was treated with insulin. The average duration of dialysis was $49.7 \pm 44.3$ months. Six patients had ischemic heart disease, and one patient had dilated cardiomyopathy. One patient was prescribed enalapril ; one, losartan ; three, valsartan ; and two, telmisartan. RA inhibitors were gradually increased to $82.1 \pm 24.9 \%$ of the target dose. Duration of treatment and observation was 12.6 6 8. 8 months. DW increased from $57.6 \pm 7.6$ to $61.5 \pm 8.3 \mathrm{~kg}$ after treatment. CTR decreased from $52.3 \pm 4.5$ to $48.9 \pm$ 5. $3 \%$. LAD decreased from $45.7 \pm 6.4$ to $39.7 \pm 6.7 \mathrm{~mm}$. LVDd decreased from $60.9 \pm 3.2$ to $52.2 \pm 5.5 \mathrm{~mm}$.

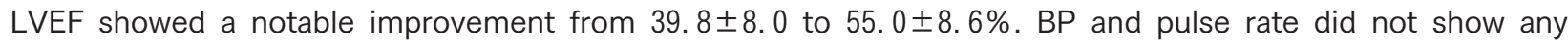
significant change. Following treatment with RA inhibitors, despite a DW increment, CTR decreased and LV function improved in diabetic dialysis patients with CHF.

\section{はじめに}

透析療法の進歩にもかかわらず，うっ血性心不全は 依然として透析患者の死因の第 1 位である ${ }^{1)}$.

慢性心不全は心筋収縮性の低下した収縮性心不全と 心筋拡張性の低下した拡張期心不全に分類される ${ }^{2,3)}$.

透析患者の心不全においては拡張期心不全が多いと 報告されているが，拡張期心不全の治療方針は未だ 確立されていない2,3).

慢性収縮性心不全においてはアンジオテンシン変換 酵素 (ACE) 阻害薬, アンジオテンシン II 受容体ブロッ カー（ARB）といったレニン・アンジオテンシン系抑 制薬（以下 RA 系抑制薬）の有効性が確立されてい $ろ^{2)}$.

透析治療において, dry weight（DW）は血圧管理, 心血管系合併症防止のうえで重要で, 特に心不全合併 例では適切な DW 維持が必要である ${ }^{5,6)}$. しかしなが ら心疾患を合併した患者では DW 設定が困難な場合 があり，特に重症例ほどその安全域は狭く，容易にそ の過大による心不全，過小による血圧低下をきたす5). 近年, 透析導入例における糖尿病 (DM) 患者の割合 は年々増大している ${ }^{1)}$ 。非 DM 例と比較して DM 例に おいては透析中の血圧低下が多く，これには虚血性心 疾患合併の頻度が高いことが関連するとの報告があ $り^{7)}$, 特に心不全合併時には透析時血圧が不安定性で, 適切な DW の設定，維持に難渋する場合がある。こ のため, DM 透析慢性収縮性心不全において薬物療法, 特に RA 系抑制薬の有効性が期待される.

慢性収縮性心不全において，非透析例では RA 系抑 制薬は薬剤認容性をみながら漸増し，投与量の多い方 が有効性は高いと考えられている2). しかし ATLAS ${ }^{8)}$ においては ACE 阻害薬である lisinopril の低容量群 と高用量群の比較がなされているが，RA 系抑制薬の 投与方法に関する長期間の大規模な検討は未だ十分行 われていない ${ }^{9 \sim 17)}$. さらに今回検索できた範囲内で,
特に透析例において RA 系抑制薬の投与法に関する検 討は不十分であった.

さらに RA 系抑制薬については以下の検討課題も考 えられる。すなわち，1．血圧低下への対応，2．血 清 $\mathrm{K}$ 上昇の可能性，3. ACE 阻害薬と ARB 間，およ び薬剤間の有効性の差, 4. ACE 阻害薬と ARB の併 用療法, 5. 適応症例である.

まず，今回われわれは慢性収縮性心不全を合併した DM 透析患者において以下の検討を行った.

\section{I. 目的}

慢性収縮性心不全を合併した DM 透析患者におい て RA 系抑制薬の有効性を検討する.

\section{II. 対 象}

対象は当院で維持透析中の, DM を合併した慢性収 縮性心不全患者.

心臓カテーテル検査, 心エコー検査で狭窄性弁膜症, 肥大型閉塞性心筋症などの狭窄性心疾患, ASD, VSD, PDA などのシャント性疾患, 心夕ンポナーデ, 収縮性 心外膜炎，心筋炎を除外し，心エコーで EF 50\%未満 の症例を慢性収縮性心不全とした。

\section{III. 方 法}

投与薬剂として ACE 阻害薬は enalapril, ARB は losartan, valsartan, telmisartan を用いた。

投与方法は開始量を各薬剤常用量上限の $1 / 16 \sim 1 / 8$ 量, 目標投与量は各薬剤常用量の上限とした。薬剤認 容性をみながら可能な限り 1〜2 週ごとに開始量を追 加してなるべく目標量まで漸増した.

血圧低下に対しては DW $0.5 〜 1 \%$ す増加させ て血圧維持に努めた。

治療前後の透析時血圧, 脈拍数, 心胸比 (CTR), 
表 1 患者背景因子

\begin{tabular}{lc}
\hline Number & 7 \\
Age (years) & $64.4 \pm 8.7$ \\
Gender (male/female) & $7 / 0$ \\
BMI (kg/m²) & $22.0 \pm 2.9$ \\
Duration of diabetes (years) & $10.9 \pm 11.4$ \\
HbAlc (\%) & $6.5 \pm 1.6$ \\
Diabetes therapy (D : O : I) & $2: 4: 1$ \\
Etiology of CRF (DN : CGN) & $6: 1$ \\
Duration of HD (months) & $1: 6$ \\
Etiology of CHF (DCM : IHD) & \\
\hline D : diet, O : oral hypoglycemic agemts, I : insulin, DN : \\
diabetic nephropathy, CGN : chronic glomerulonephritis, \\
HD : hemodialysis, CHF : congestive heart failure, DCM : \\
dilated cardiomyopathy, IHD : ischemic heart disease (no \\
myocardial infarction)
\end{tabular}

DW，心エコー所見を比較検討した.

この間ほかの降圧剤の追加, 中止, 増減は行わなかっ た。

胸部 X 線撮影, 心エコー検査は透析後に行った. 心エコー装置は東芝 SSA-550A, $3.3 \mathrm{MHz}$ プローブを 用い, 記録は傍胸骨長軸像・短軸像, 心尖部四腔像, 二腔断面の 4 断面で行った.

さらに治療前後の血清タンパク, ヘモグロビン，へ マトクリット, 脂質, 血糖值, HbAlc, BUN, クレア チニン, $\mathrm{K}$, 尿酸, $\mathrm{Ca}$, リン, $\mathrm{iPTH}, \mathrm{Kt} / \mathrm{V}$, 体重増加 率 (週初め 2 日あきの時点での DW に対する増加率), さらに BNP も比較検討した. Kt/V は single pool モ デルによる Daugirdas の二点法 ${ }^{18)}$ を用いて計算した. 採血はいずれも食後採血とした.

数值は, 平均值 標準偏差で示し, 治療前後の比較 は the paired t test を用い, $\mathrm{p}<0.05$ を統計学的に有 意とした.

\section{IV. 結 果}

症例は 7 例, 全例男性, 年齢 $64.4 \pm 8.7$ 歳, BMI $22.0 \pm 2.9 \mathrm{~kg} / \mathrm{m}^{2}$. 糖尿病罹病期間 $10.9 \pm 11.4$ 年, HbAlc $6.5 \pm 1.6 \%$ ．糖尿病治療は食事療法 2 例, 経 口血糖降下剂 4 例，インスリン治療 1 例. 透析期間 $49.7 \pm 44.3$ か月. 心不全は全例 NYHA class II . 心 疾患は DCM 1 例, 虚血性心疾患 6 例（心筋梗塞例な し）（表 1). 投与薬剤は valsartan 3 例, telmisartan 2 例, losartan 1 例, enalapril 1 例. RA 系抑制薬の目標 投与量に対して到達した投与量は $82.1 \pm 24.9 \%$, 投与 開始時からの投与期間（観察期間）12.6土8.8 か月で あった。

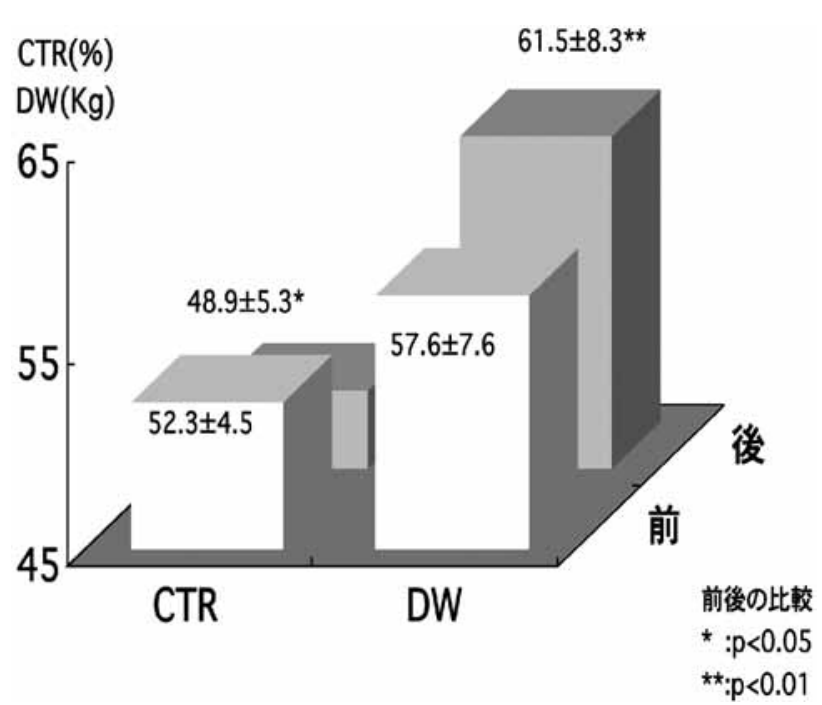

図 1 治療前後の CTR, DW 変化

CTR は治療前 $52.3 \pm 4.5 \%$ から治療後 $48.9 \pm 5.3 \%$ と治療後は有意に縮小したが（図 1, p<0.05), DW は治療前 $57.6 \pm 7.6 \mathrm{~kg}$, 治療後 $61.5 \pm 8.3 \mathrm{~kg}$ と治療 後に有意に増加していた（図 1, p<0.01）.

心エコー所見（図 2）を検討すると，LAD は治療前 $45.7 \pm 6.4 \mathrm{~mm}$ から治療後 $39.7 \pm 6.7 \mathrm{~mm}$ と投与後に 有意減少 $(\mathrm{p}<0.05)$. LVDd は治療前 $60.9 \pm 3.2 \mathrm{~mm}$, 治療後 $52.2 \pm 5.5 \mathrm{~mm}$ と投与後有意縮小 $(\mathrm{p}<0.05)$.

LVDs も治療前 $49.9 \pm 4.4 \mathrm{~mm}$, 治療後 $37.4 \pm 5.9$ $\mathrm{mm}$ に投与後有意減少 $(\mathrm{p}<0.01)$. LVEF も投与前 $39.8 \pm 8.0 \%$, 投与後 $55.0 \pm 8.6 \%$ と治療後有意改善し た $(\mathrm{p}<0.001)$.

以上のように DW 増加にもかかわらず CTR, 左心 房径, 左心室径は縮小し, LVEF も上昇するなど, 左 心機能改善を示した。

さらに目標投与量を最も長期間継続できた 1 症例で LVEFを経時的に検討すると, 目標投与量到達時 $49.6 \%, 2$ か月後 $52 \%, 4$ 少後 $49 \%, 6$ か月後 $55 \%$, 10 か月後 $61 \%$ と経時的に LVEF 改善傾向を認めた (図 3).

透析時血圧を RA 系抑制薬投与前後で検討した（図 4). 透析開始時血圧は投与前 $144.9 \pm 20.3 / 72.1 \pm$ $11.6 \mathrm{mmHg}$, 投与後 $153.0 \pm 16.5 / 76.3 \pm 10.9 \mathrm{mmHg}$. 最低血圧は投与前 $117.6 \pm 17.1 / 59 \pm 11.4 \mathrm{mmHg}$, 投 与後 $111.3 \pm 13.7 / 56.1 \pm 7.6 \mathrm{mmHg}$. 終了時血圧は 投与前 $132 \pm 20.5 / 64.8 \pm 15.4 \mathrm{mmHg}$, 投与後 129.5 $\pm 10.8 / 66.7 \pm 4.5 \mathrm{mmHg}$. 以上のように投与前後で 透析時血圧に有意差を認めなかった。

さらに透析時脈拍数をみると, 開始時は投与前 81.1 \pm 7.9 /分, 投与後 $82 \pm 10.9$ /分. 最低血圧時の脈拍数 は投与前 $79 \pm 3.7 /$ 分, 投与後 $76.3 \pm 11.1$ /分. 終了時 

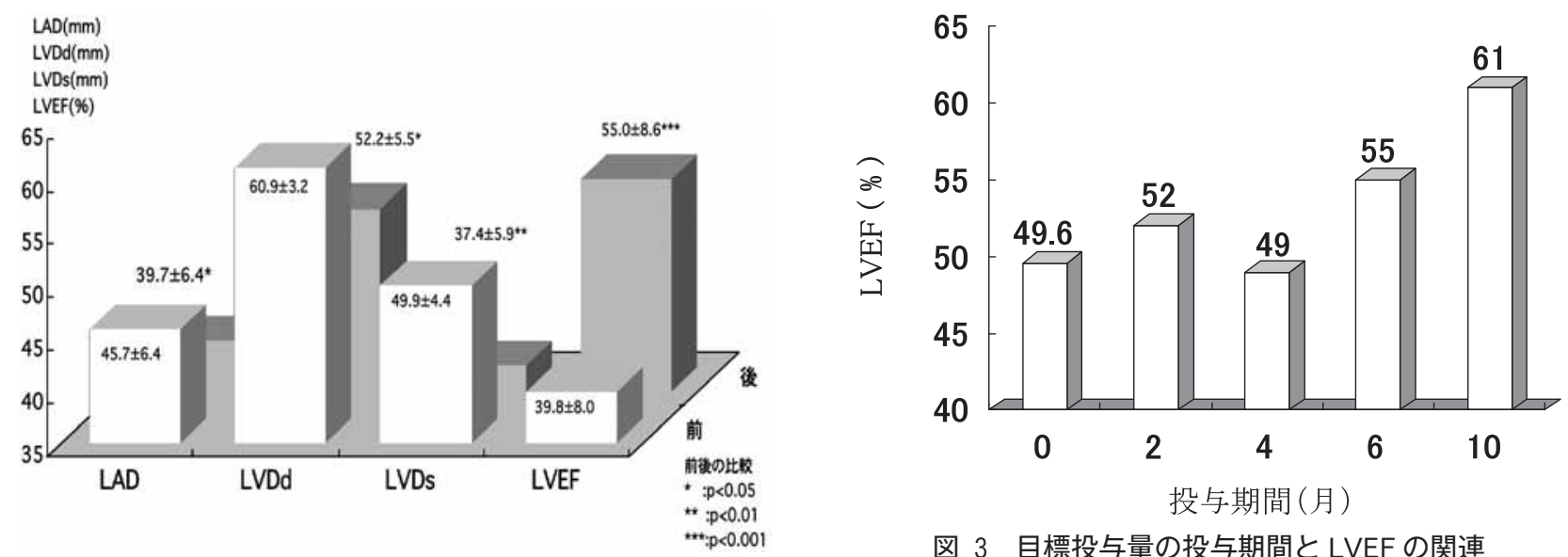

図 2 治療前後の LAD, LVDd, LVDs, LVEF 変化

図 3 目標投与量の投与期間と LVEF の関連

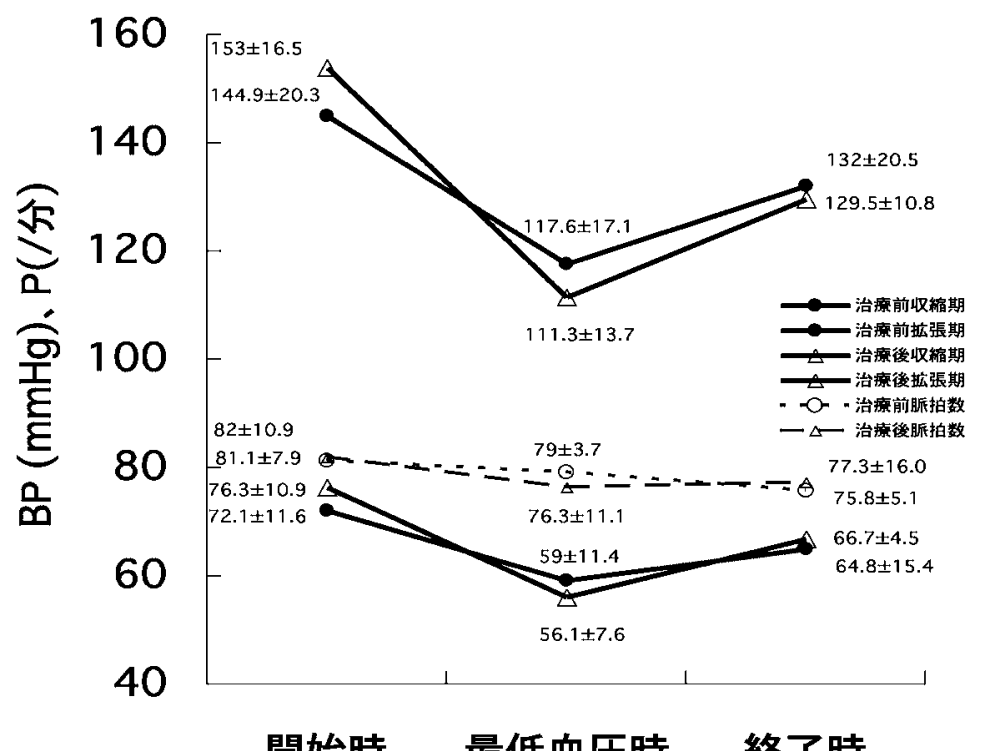

開始時 最低血圧時 終了時

図 4 治療前後の透析時血圧, 脈拍数変化

脈拍数は投与前 $75.8 \pm 5.1$ /分, 投与後 $77.3 \pm 16.0$ /分.

脈拍数も投与前後で有意差を認めなかった（図 4).

治療後で HDL-C の減少（表 2, p < 0.01），食後 TG の増加（表 2, p<0.05）を認めたが, 血清タンパク, ヘモグロビン, TC, LDL-C, 血糖值, HbAlc は治療 前後で有意差認めず (表 2), BUN, クレアチニン, $\mathrm{K}$, 尿酸, $\mathrm{Ca}, \mathrm{iPTH}, \mathrm{Kt} / \mathrm{V}$, 体重増加率（週初め 2 日あき での DW に対する）も治療前後で有意差を認めなかっ た（表 3). BNP は透析後低下しているが, 症例数が 2 例と少なく，有意差は認めなかった。

また DW 増加に伴う心不全症状の悪化例は認めず, RA 系抑制薬投与による咳, 経過中の血圧低下に伴う シャント不全発症, ASO 悪化も認めなかった。

\section{V. 考察}

慢性収縮性心不全においては交感神経系, レニン・ アンジオテンシン系が賦活され，これより左室リモデ リングを生じ, 進行性の左室拡大と収縮能低下につな がると考えられている。このような神経内分泌系を $\beta$ 遮断薬，ACE 阻害薬，ARBにより阻害することで左 室リモデリングを抑制し，心不全の予後を改善するこ とが最近の慢性心不全治療の中心となっている ${ }^{2,3)}$.

今回の検討では RA 系抑制薬の種類, 投与量, 投与 期間もさまざまであったが，DW の設定，維持が困難 な糖尿病透析慢性収縮性心不全患者においても RA 系 抑制薬が有効であることが明らかとなった。

非透析患者では慢性収縮性心不全において RA 系抑 制薬投与が推奨されている ${ }^{4}$ が，投与方法についての 
表 2 生化学検査所見

\begin{tabular}{l|c|c|c}
\hline & 治療前 & 治療後 & $\mathrm{p}$ \\
\hline $\mathrm{TP}(\mathrm{g} / \mathrm{dL})(\mathrm{n}=7)$ & $6.7 \pm 0.5$ & $6.5 \pm 0.5$ & $\mathrm{n} . \mathrm{s}$. \\
$\mathrm{Alb}(\mathrm{g} / \mathrm{dL})(\mathrm{n}=7)$ & $3.5 \pm 0.3$ & $3.5 \pm 0.2$ & $\mathrm{n} . \mathrm{s}$ \\
$\mathrm{Hb}(\mathrm{g} / \mathrm{dL})(\mathrm{n}=7)$ & $10.2 \pm 0.8$ & $10.3 \pm 1.2$ & $\mathrm{n} . \mathrm{s}$. \\
$\mathrm{Ht}(\%)(\mathrm{n}=7)$ & $32.5 \pm 3.4$ & $32.1 \pm 2.8$ & $\mathrm{n} . \mathrm{s}$. \\
$\mathrm{TC}(\mathrm{mg} / \mathrm{dL}) \quad(\mathrm{n}=7)$ & $148.3 \pm 28.3$ & $164.7 \pm 26.5$ & $\mathrm{n} . \mathrm{s}$. \\
$\mathrm{HDL}-\mathrm{C}(\mathrm{mg} / \mathrm{dL})(\mathrm{n}=7)$ & $40.6 \pm 10.6$ & $33.9 \pm 8.0$ & $\mathrm{p}<0.01$ \\
$\mathrm{LDL}-\mathrm{C}(\mathrm{mg} / \mathrm{dL})(\mathrm{n}=7)$ & $80.4 \pm 21.5$ & $92.0 \pm 19.4$ & $\mathrm{n} . \mathrm{s}$. \\
$\mathrm{TG}(\mathrm{mg} / \mathrm{dL}) \quad(\mathrm{n}=4)$ & $145.5 \pm 81.7$ & $231.3 \pm 74.3$ & $\mathrm{p}<0.05$ \\
$\mathrm{BS}(\mathrm{mg} / \mathrm{dL}) \quad(\mathrm{n}=7)$ & $163.4 \pm 46.6$ & $146.9 \pm 62.2$ & $\mathrm{n} . \mathrm{s}$. \\
$\mathrm{HbAlc}(\%) \quad(\mathrm{n}=7)$ & $6.6 \pm 1.6$ & $7.0 \pm 2.0$ & $\mathrm{n} . \mathrm{s}$. \\
\hline
\end{tabular}

\section{表 3 検査所見}

\begin{tabular}{|c|c|c|c|}
\hline & 治療前 & 治療後 & $\mathrm{p}$ \\
\hline BUN (mg/dL) $(n=7)$ & $67.0 \pm 11.8$ & $71.5 \pm 17.9$ & n. s. \\
\hline CRE $(\mathrm{mg} / \mathrm{dL}) \quad(\mathrm{n}=7)$ & $8.7 \pm 3.3$ & $10.3 \pm 2.2$ & n. $\mathrm{s}$. \\
\hline $\mathrm{K} \quad(\mathrm{mEq} / \mathrm{L}) \quad(\mathrm{n}=7)$ & $4.3 \pm 0.8$ & $4.7 \pm 0.7$ & n. s. \\
\hline $\mathrm{UA}(\mathrm{mg} / \mathrm{dL}) \quad(\mathrm{n}=7)$ & $7.6 \pm 1.1$ & $7.2 \pm 0.6$ & n. $\mathrm{s}$. \\
\hline $\mathrm{Ca}(\mathrm{Alb}$ 補正值 $) \quad(\mathrm{mg} / \mathrm{dL}) \quad(\mathrm{n}=7)$ & $9.3 \pm 0.4$ & $9.0 \pm 0.4$ & n. s. \\
\hline$P(m g / d L) \quad(n=7)$ & $5.3 \pm 0.9$ & $4.9 \pm 1.7$ & n. s. \\
\hline $\operatorname{ALP}(\mathrm{U} / \mathrm{L}) \quad(\mathrm{n}=7)$ & $237.6 \pm 53.2$ & $211.3 \pm 39.5$ & n. s. \\
\hline $\operatorname{Mg}(\mathrm{mg} / \mathrm{dL}) \quad(\mathrm{n}=7)$ & $2.3 \pm 0.2$ & $2.4 \pm 0.2$ & n. s. \\
\hline iPTH $(\mathrm{pg} / \mathrm{mL}) \quad(\mathrm{n}=7)$ & $96.1 \pm 47.5$ & $150.9 \pm 181.9$ & n. s. \\
\hline$\beta_{2}-$ microglobulin $(\mathrm{mg} / \mathrm{L}) \quad(\mathrm{n}=7)$ & $24.3 \pm 5.5$ & $25.9 \pm 3.3$ & n. $\mathrm{s}$. \\
\hline $\mathrm{Kt} / \mathrm{V} \quad(\mathrm{n}=5)$ & $1.3 \pm 0.2$ & $1.4 \pm 0.1$ & n. s. \\
\hline 体重増加率（\%）（n=5） & $6.1 \pm 2.4$ & $5.7 \pm 1.6$ & n. s. \\
\hline $\mathrm{BNP}(\mathrm{pg} / \mathrm{mL}) \quad(\mathrm{n}=2)$ & $192.5 \pm 77.1$ & $47.7 \pm 14.1$ & n. s. \\
\hline
\end{tabular}

$\mathrm{Kt} / \mathrm{V}=-\mathrm{In}(\mathrm{R}-0.008 \times \mathrm{t})+(4-3.5 \times \mathrm{R}) \times \mathrm{UF} / \mathrm{BW}$

$(\mathrm{R}=\mathrm{Cl} / \mathrm{C} 0, \mathrm{C} 0$ : 透析開始時の BUN $(\mathrm{mg} / \mathrm{dL}), \mathrm{Cl}$ : 透析終了時の BUN $(\mathrm{mg} / \mathrm{dL})$ $\mathrm{t}$ : 透析時間 (時間), UF : 総限外滤過量 $(\mathrm{kg}), \mathrm{BW}$ : 透析後体重 $(\mathrm{kg}))$ 増加率 : 週初め 2 日あきでの DW に対する体重増加

詳細な検討は少ない，ATLAS では ${ }^{8)}$ 低容量群と高用 量群の比較が行われているが, 多くの ACE 阻害

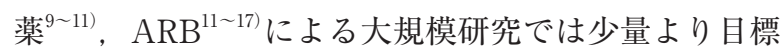
投与量まで漸増され，目標投与量での効果が検討され ている. ACE 阻害薬は低用量より高用量で効果がよ

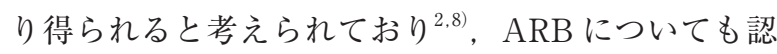
容性をみながら漸増することが推奨されている2．

われわれの検討においても可能な限り RA 系抑制薬 は常用量上限まで増量を行った. RA 系抑制薬投与に 伴う血圧低下が懸念されたが， RA 系抑制薬の少量を 1 2 週間隔で漸増し，血圧低下に対しては DWを 0.5 １\%ずつ増加させることにより， RA 系抑制薬の 漸增投与が可能であった.

今回の検討において，1症例ではあるが投与目標量 到達後, 経時的に $\mathrm{EF}$ 改善傾向を認め, 投与継続によ り経時的に左心機能が改善する可能性も示唆された.

今後, 症例を増やして左心機能と RA 系抑制薬の投
与方法, 投与量との関連についてさらに検討する必要 がある.

さらに $\mathrm{ACE}$ 阻害薬において, その長期投与後に血 漿中アルドステロン濃度が抑制されなくなってくる現 象である aldosteron breakthrough が知られている が ${ }^{19)}$ ，ARB 長期投与でも同様の現象が報告されてお $\eta^{20)}$, ACE 阻害薬， ARB 長期投与の効果についても なお検討が必要である。

また非透析例のように ACE 阻害薬と ARB の併用 効果 ${ }^{8}$ があるかについても検討が必要である.

今回の検討では RA 系抑制薬は ACE 阻害薬として enalapril, ARB としてlosartan, valsartan, telmisartan を用いたが，今後は ACE 阻害薬と ARB の比 較， $\mathrm{ACE}$ 阻害薬， $\mathrm{ARB}$ それぞれに扔ける薬剤間の有 効性の差についても検討の必要がある.

血圧低下に対して DW 増加で対応し, DW 増加に もかかわらず左心系拡張, 左心機能が改善した原因と 
して, (1) 栄養状態の改善による lean body mass, 体脂 肪量増加, (2) 透析手技, 透析条件, 水分コントロール による左心機能改善のほかに, (3) RA 系抑制薬投与に より体液分布が変化した可能性も考えられた。（1)：聞 き取りによる食事摂取状況の変化はなく，治療後に食 後 TG は増加しているが, TP, Alb, Hb, TC, BS, $\mathrm{HbAlc}$ の有意変化はないことから栄養状態改善によ る体重増加は明らかではなかった. Lean body mass, 体脂肪量増加の可能性についてさらに検討が必要と考 えられる. (2) : 治療前後で透析手技の変更はなされて おらず, 透析間体重増加, $\mathrm{Kt} / \mathrm{V}$ に有意差なく, 透析手 技, 透析条件, 水分コントロール改善による左心機能 改善では説明しがたいと考えられた。 (3)：RA 系抑制 薬投与により体液分布が変化した可能性については, 今回検索できた範囲ではそのような報告はなく, 今後 body composition analyzer などを用いた検討も必要 ではないかと考えられた。

RA 系抑制薬の適応症例は当面, 収縮性心不全と考 えられ, 適応除外症例としては重篤な狭窄性心疾患, 慎重投与症例は拡張期心不全, 重篤な ASO, シャント 不全例があげられる。

今回の検討では有意なカリウム上昇, 咳は認めな かったが, 今後さらに症例を増やした検討が必要であ る.

患者にとって RA 系抑制薬は降圧剂のイメージが強 く, RA 系抑制薬投与により血圧低下をきたし, $\mathrm{DW}$ 調整を必要とすることもあり，今回の検討において服 薬コンプライアンス維持にはかなり困難であったが, 透析患者における RA 系抑制薬の左心機能, 予後への 影響に関する充分な評価のためには今後大規模な長期 的研究が必要であると考えられる.

今回，透析患者における RA 系抑制薬の有効性の検 討を DM 合併例で行ったが，今後非 DM 患者におけ る検討の必要性もあると考えられる.

\section{文献}

1) 中井 滋, 政金生人, 秋葉 隆, 重松 隆, 山縣邦弘, 渡邊有三, 井関邦敏, 伊丹儀友, 篠田俊雄, 両角國男, 庄司哲雄, 丸林誠二, 守田 治, 木全直樹, 勝二達也, 鈴木一之, 土田健司, 中元秀友, 濱野高行, 山下明泰, 若井健志, 和田篤志, 椿原美治（日本透析医学会統計 調査委員会, 同小委員会) : 我が国の慢性透析療法の現 況（2006 年 12 月 31 日現在）。透析会誌 $41: 1-28$, 2008

2) Hunt SA, Abraham WT, Chin MH, Feldman AM, Francis GS, Ganiats TG, Jessup M, Konstam MA, Mancini DM, Michl K, Oates JA, Rahko PS, Silver MA,
Stevenson LW, Yancy CW, Antman EM, Smith SC Jr, Adams CD, Anderson JL, Faxon DP, Fuster V, Halperin JL, Hiatzka LF, Hunt SA, Jacobs AK, Nishimura R, Ornato JP, Page RL, Riegel B : ACC/ AHA 2005 Guideline Update for the Diagnosis and Management of Chronic Heart Failure in the Adult : a report of the American College of Cardiology/American Heart Association Task Force on Practice Guidelines (Writing Committee to Update the 2001 Guidelines for the Evaluation and Management of Heart Failure) : developed in collaboration with the American College of Chest Physicians and the International Societey for Heart and Lung Transplantation: endorsed by the Heart Rhythm Society. Circulation 112 : e154-e235, 2005

3）日本循環器学会：慢性心不全治療ガイドライン（2005 年改訂版). http://www.j-circ.or.jp/guideline/index. htm

4) 田村忠司, 太田 真, 佐藤成明, 杉本健一, 田中 博, 宇都宮正範, 齋藤広重, 岡田秀雄, 池田恵一, 川口良 人, 酒井 紀：血液透析患者における左室流入および 肺静脈血流動態の検討. 透析会誌 $28: 1437-1442$, 1995

5) Jaeger JQ, Mehta RL : Assessment of dry weight in hemodialysis : An overview. J Am Soc Nephrol 10 : 392-403, 1999

6）安藤康宏：ドライウエイトの決め方. 透析療法におけ る心・血管系合併症と対策 [改訂第 2 版]（浅野 泰監 修. 草野英二, 田部井薰編), p237-247, 日本メディカ ルセンター, 東京, 2008

7）原茂子，香取秀幸，乳原善文：末期糖尿病性腎症に 対する透析療法と問題点. 日本臨牀 60 (増刊号 10)： 306-315, 2002

8) Packer M, Poole-Wilson PA, Armstrong PW, Cleland JGF, Horowitz JD, Massie BM, Ryden L, Thygesen K, Uretsky BF : Comparative effects of low and high doses of the angiotensin-converting enzyme inhibitor, lisinopril, on morbidity and mortality in chronic heart failure. Circulation $100:$ 2312-2318, 1999

9) The SOLVD Investigators : Effect of enalapril on survival in patiens with reduced left ventricular ejection fractions and congestive heart failure. N Engl J Med 325 : 293-302, 1991

10) The Consensus Trial Study Group : Effects of enalapril on mortality in severe congestve heart failure. Results of the Cooperative North Scandinavian Enalapril Survival Study (CONSENSUS). N Engl J Med 316 : 1429-1435, 1987

11) Pitt B, Poole-Wilson PA, Segal R, Martinez FA, Dickstein K, Camm AJ, Konstam MA, Riegger G, Klinger GH, Neaton J, Sharma D, Thiyagarajan B : Effect of losartan compared with captopril on mortality in patients with symptomatic heart failure : 
randominzed trial-the Losartan Heart Failure Survival Study ELITE II . Lancet 355 : 1582-1587, 2000

12) Pfeffer MA, Swedberg K, Granger CB, Held P, McMurray JJV, Michelson EL, Olofsson BE, Östergren J, Yusuf S : Effects of candesartan on mortality and morbidity in patients with chronic heart failure : the CHARM-Overall programme. Lancet $362: 759$ 766, 2003

13) McMurray JJV, Östergren J, Swedberg K, Granger CB, Held P, Michelson EL, Olofsson B, Yusuf S, Pfeffer MA : Effects of candesartan in patients with chronic heart failure and reduced left-ventricular systolic function taking angiotensin-convering-enzyme inhibitors : the CHARM-Added trial. Lancet $362: 767-771$, 2003

14) Granger CB, McMurray JJV, Yusuf S, Held P, Michelson EL, Olofsson B, Östergren J, Pfeffer MA, Swedberg K : Effects of candesartan in patients with chronic heart failure and reduced left-ventricular systolic function intolerant to angiotensin-convertigenzyme inhibitors: the CHARM-Alternative trial. Lancet $362: 772-776,2003$

15) Yusurf S, Pfeffer MA, Swedberg K, Granger CB, Held P, McMurray JJV, Michelson E, Olofsson B, Östergren $\mathrm{J}$ : Effects of candesartan in patients with chronic heart failure and preserved left-ventricular ejection fraction : the CHARM-Preseved trial. Lancet 362 : 777-781, 2003

16) Matsumori A : Efficacy and safety of oral candesartan cilexetil in patients with congestive heart failure. Eur J Heart Fail 5 : 669-677, 2003

17) Cohn JN, Tognoni $G: A$ randomized trial of the angiotensin-receptor blocker valsartan in chronic heart failure. N Engl J Med 345 : 1667-1675, 2001

18) Daugirdas JT : Second generation logarithmic estimates of single-pool variable volume $\mathrm{Kt} / \mathrm{V}:$ an analysis of error. J Am Soc Nephrol $4: 1205-1213$, 1993

19) Sato A, Saruta $T$ : Aldosterone breakthrough during angiotensin-converting enzyme inhibitor therapy. AJH $16: 781-788,2003$

20) McKelvie RS, Yusuf S, Pericak D, Avezum A, Burns RJ, Probstfield J, Tsuyuki RT, White M, Rouleau J, Latini R, Maggioni A, Young J, Pogue J : Comparison of Candesartan, Enalapril, and Their Combination in Congestive Heart Failure : Randomized Evaluation of Strategies for Left Ventricular Dysfunction (RESOLVD) Pilot Study. Circulation $100: 1056-1064$, 1999 